\title{
A feedback loop: Interactions between Inflammatory Signals and Clonal Hematopoiesis in Cardiovascular Disease
}

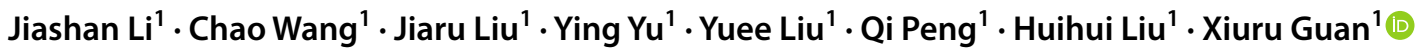

Received: 28 October 2020 / Accepted: 23 April 2021 / Published online: 13 May 2021

(c) The Author(s), under exclusive licence to Springer Nature B.V. 2021

\begin{abstract}
Age and inflammation are powerful drivers of cardiovascular disease. With the growing recognition that traditional cardiovascular risk factors are not fully accurate predictors of cardiovascular disease, recent studies have revealed the prevalence of positive selection of somatic cell mutations in hematopoietic stem cells in the elderly population, which can cause clonal hematopoiesis. Interestingly, clonal hematopoiesis is not only associated with cancer and death, but also closely related to the risk of increased cardiovascular disease due to mutations in TET2, DNMT3A, ASXL1, and JAK2. However, the mechanism of the interaction of clonal hematopoiesis and cardiovascular disease is only partially understood. In mice, somatic mutations have led to significantly increased expression of inflammatory genes in innate immune cells, which may explain the relationship between mutations and cardiovascular disease. Here, we further discuss the association between inflammatory signaling, clonal hematopoiesis, and cardiovascular disease, and using two hypotheses to propose a feedback loop between inflammatory signaling and clonal hematopoiesis for getting insight into the pathogenesis of cardiovascular diseases in depth. Therapies targeting mutant clones or increased inflammatory mediators may be useful for ameliorating the risk of cardiovascular disease.
\end{abstract}

Keywords Inflammation · Clonal hematopoiesis · Cardiovascular disease · Somatic cell mutation · Aging · Hematopoietic stem cells

\begin{tabular}{ll}
\multicolumn{2}{l}{ Abbreviations } \\
TET2 & Ten-eleven Translocation 2 \\
DNMT3A & DNA methyltransferase 3a \\
ASCL1 & Additional sex combs-like 1 \\
JAK2 & Janus kinase 2 \\
CHIP & Clonal hematopoiesis of indeterminate \\
& potential \\
VAF & Variant allele frequency \\
CAD & Cardiac artery disease \\
CVD & Cardiovascular disease \\
CH & Clonal hematopoiesis \\
HF & Heart failure \\
TLR & Toll-like receptor4 \\
HSPC & Hematopoietic stem-progenitor cell \\
HSCs & Hematopoietic stem cells \\
NETs & Neutrophil extracellular traps \\
MPN & Myeloproliferative tumors
\end{tabular}

Xiuru Guan

gxr0451@sina.com

1 First Affiliated Hospital of Harbin Medical University, Harbin 150001, China

\begin{abstract}
AML Acute Myeloid Leukaemia
BMT Bone Marrow Transplantation
\end{abstract}

\section{Introduction}

\section{Age-related somatic mutations and clonal hematopoiesis}

Mutations accumulate steadily over time in almost all types of tissue as a result of unavoidable random mutations that mainly arise during DNA replication. Mutations are associated with cancer, but the large variation in cancer incidence among these different tissues harboring mutations [1-3]. And most somatic mutations are harmless, only a few mutations affect a gene or regulatory element,contributing to a phenotypic consequence[4]. A fraction of these mutations can confer the cells a competitive advantage, resulting in the clone expansion of the hematopoietic stem and progenitor cells(HSPCs) or clonal hematopoiesis, that is expanded somatic cell clone derived from a single mutant progenitor cell $[1,5]$. An individual with clonal hematopoiesis has 
a significantly increased risk of developing hematologic malignancy $[6,7]$. Clonal hematopoiesis with variant allele frequency $(\mathrm{VAF})>2 \%$ carries the risk of developing malignant blood tumors but does not meet the blood malignancy diagnostic criteria, namely clonal hematopoiesis of Indeterminate potential(CHIP), which applies to those with mutant clones that exceed $2 \%$ of their peripheral leukocyte count [8]. The proposed VAF of $2 \%$ is arbitrary and may need to be adjusted as further information accumulates. The threshold of mutation detection, to some extent, depends on the analytical technique used[9]. Maybe the clinically relevant VAF needs to be determined for every gene, mutation and disease. Most CHIP carriers have only one gene mutation, but cells of blood cancer patients may be detected multiple mutations. Interestingly, a recent study has reported that clonal hematopoiesis also occurs with age even in the absence of candidate driver mutations. Meanwhile, other teams have found that smaller clones at the $\mathrm{VAF}<2 \%$ are common in populations older than 50 years of age [10,11]. However, it is unknown whether smaller clones, are associated with the risk of malignancy and other diseases.Additionally, Genovese et al. used undifferentiated exon sequencing analysis to detect unknown driver mutations in clonal hematopoiesis, and the results showed that unknown driver mutations accounted for $40 \%$ of the detected clone events [7]. It should be noted that clonal hematopoiesis in the absence of known driver mutations also can exist, which may be caused by genetic drift in normal aging HSPCs, mutations in unidentified driver genes, or a heritable epigenetic trait [12-14].

Detectable somatic mutations are rare in populations under the age of 40, but their frequency increases with age. Among persons 70 to 79 years of age, 80 to 89 years of age, and 90 to 108 years of age, these clonal mutations were detected in $9.5 \%$ ( 219 of 2300 persons), $11.7 \%$ (37 of 317), and $18.4 \%$ (19 of 103), respectively [6]. At the same time, the study also showed that the increased risk of hematologic malignancies was closely related to the presence of somatic cell mutations, among which three genes were most frequently mutated, namely DNMT3A, TET2, and ASXL1[6, 15]. There are several causes for age-related mutations, the most common one of which occurs during the $\mathrm{CpG}$ dinucleotide methylation phase, in which 5-methylcytosine is deaminated to thymine [16], and this spontaneous process is linear with time and is considered as a sign of aging [17]. The second type of mutations is small insertions and deletions due to errors caused by non-homologous DNA terminal double strand breaks, which can cause frame shift if the break occurs in the protein-coding region [18]. Studies have shown that double strand breaks are more likely to occur as cells age [19]. A third cause of mutations is replication errors caused by DNA polymerase, typically base substitutions and small insertion deletions. But the probability of DNA replication errors in eukaryotic cells is very low, unless DNA mismatch repair is impaired [20,21]. The number of cell replication cycles increases with age, so does the number of polymerase errors [22]. The fourth type of age-related mutations is large structural variations such as insertion, deletion, heterozygote deletion or thousand-base rearrangement that rarely occur [23].

\section{Relationship between CHIP and risk of cardiovascular disease in humans}

CHIP is very common in the elderly population, with approximately $10 \%$ of individuals older than 70 harboring at least one mutation in their white blood cells [6]. CH is also common in younger individuals, and the method and its sensitivity used for VAF strongly impact the prevalence of $\mathrm{CH}$ in the reported age groups. A study using error-corrected sequencing, which allows for detecting clonal events at as low as $0.03 \% \mathrm{VAF}$, found that mutations in selected candidate driver genes occurred in $95 \%$ of individuals aged 50-70 years, an age group for which previous studies assessed that only $5 \%$ of individuals had detectable clonal hematopoiesis [11]. Compared with non-CHIP carriers, CHIP carriers had a roughly tenfold increased risk of developing hematological malignancies, but most did not develop malignant tumors such as leukemia [6, 8].

More recently, some findings have focused on the relationship between clonal hematopoiesis with or without a candidate driver gene and increased all-cause mortality. Studies have found that individuals carrying CHIP have a 40 to 50 percent increased all-cause mortality [6, 7].And the correlation was particularly strong in people over 70 years of age [6]. Though the incidence of malignant tumor in individuals with CHIP is significantly increased, the incidence of malignant tumor is low in human overall, so cancer is not the main cause for increased all-cause mortality $[6,7]$. But why do most of the groups that contribute to the increase in all-cause mortality exhibit CHIP? Subsequent analysis provided evidence that even after adjusting for known risk factors, CHIP carriers (14\%) were twice as likely to have $\mathrm{CAD}$ and ischemic stroke as non-CHIP carriers (7\%) over 10 years. This indicates that CHIP may contribute to a higher risk of cardiovascular disease and stroke, which may be the main roots of increased all-cause mortality[6]. Several studies have confirmed this conclusion again [24, 25]. Heart failure with ischemic heart disease is connected with aging. Studies of patients with myocardial infarction and stable heart failure found that the presence of DNMT3A and TET2 mutations in bone marrow cells was associated with a risk ratio of 3.25 for all-cause mortality, most of which was due to heart failure complications. Overall survival of patients with DNMT3A or TET2 mutations with a VAF greater than 0.005 to 0.01 ; a VAF of at least 0.01 to 0.02 ; a VAF of at least 0.02 ;and non-CHIP patients reveals dose-response of 
clone size and clinical outcome.[26]. Additionally, the transcriptome profiles of peripheral blood mononuclear cells in $\mathrm{N}=6 \mathrm{HF}$ patients with DNMT3A CH-driver mutation and $\mathrm{N}=4 \mathrm{HF}$ patients without DNMT3A mutation were analyzed by single-cell RNA sequencing. This study found that circulating monocytes and T cells of patients with HF harboring clonal hematopoiesis-driver mutations in DNMT3A exhibit a highly inflamed transcriptome, which may result in the aggravation of chronic HF.[27].

Another study found that individuals with mutations in TET2, DNMT3A and ASXL1 genes had a twofold increased risk of CAD, while those with jak2-activated mutations had a tenfold increased risk of CAD [25]. From what has been discussed above, CHIP carriers may have higher risk of cardiovascular events. CHIP is independent of traditional cardiovascular risk factors including hyperlipidemia, diabetes, hypertension, stroke, etc. Therefore, CHIP will increase the risk of cardiovascular disease in humans when traditional risk factors are well controlled or do not exist [28].Moreover, individuals with CHIP had a higher risk of coronary heart disease (HR 2.0) and ischemic stroke (HR 2.6) in the multivariate analysis [25]. The risks associated with CHIP are the same or higher than those associated with traditional risk factors such as high cholesterol, smoking and high blood pressure. Meanwhile, the correlation between somatic mutations and microvascular as well as macrovascular complications in type 2 diabetes (HR 5.1) further supports the relationship between clonal hematopoiesis and atherosclerotic disease [29]. It is necessary to understand the correlation between CHIP and cardiovascular disease, and further research is needed to find out how to reduce the negative effect of CHIP on the development of disease.

\section{A causal relationship between CHIP and CVD in mice}

The aforementioned human studies suggest that CHIP is associated with cardiovascular risk, but do not fully explain the causal relationship. Biologically aging populations are prone to mutated stem cell clone and vascular disease; we think it is possible that CHIP and cardiovascular disease are both the result of aging. Individual differences in growth environment, such as smoking and drug treatment may interfere with the validation of causal relationship. In addition, there are also several factors that influence cell clone expansion such as chronic inflammation or other stress associated with cardiovascular disease such as diabetes and obesity that can cause somatic mutations and clone of mutant cells[30-32]. Therefore, animal models are powerful tools to explore the causal relationship between CHIP and cardiovascular disease [25, 33-36]. In recent years, studies have mainly focused on the loss of function in TET2/DNMT3A/ JAK2 of mouse model to prove the relationship between CHIP and cardiovascular disease, but the diversity of related driver genes in the established mouse model is insufficient. And different mutations may be associated with different diseases, which need to be further explored and differentiated in the future. Now, a large part of mouse models are knockout gene models, which may still have some limitations to be considered compared with mice carrying mutant gene. The following section reviews the adverse effects of CHIP carrying deficient or mutated genes TET2, DNMT3A, and JAK2 in mouse models on the development of cardiovascular diseases such as atherosclerosis, ischemic heart failure, and thrombosis to better understanding the causal relationship between them.

\section{Role of CHIP-related mutations in atherosclerosis}

TET2 (Ten-eleven Translocation 2) is one of the most common somatic mutant genes, which promotes clone expansion of mutant blood cells and is associated with cardiovascular disease [25]. In 2017, bone marrow was transplanted into LDLr-/- mice with atherosclerotic predisposition, $10 \%$ of which were TET2 mutated HSPCs. Bone marrow remodeling induced by TET2 mutations resulted in clonal expansion and atherosclerotic plaque enlargement with plaque increases of 50\%-70\% compared with the control group, as well as increased expression of NLRP3 inflammasome and its downstream IL-1 $\beta$. Treatment with NLRP3 inhibitor was found that there were anti-atherosclerosis effects on TET2 mutant mice, which suggests that TET2 mutations may accelerate atherogenesis by promoting the expression of NLRP3/IL-1 $\beta$ inflammatory mediators [33]. At the same time, recent studies have shown that IL- $1 \beta$ inhibitors improve cardiovascular outcomes as a therapeutic target for atherosclerosis [37]. Although the presence of CHIP was associated with the incidence of CVD, the total number of peripheral white blood cells did not change (except for the JAK2 mutation driving CHIP) [33]. On the contrary, a recent study showed that in CHIP patients with CHF, TET2 mutations are associated with a net increase of HSPCs in humans with leukocytosis in the BM[38], which is supported by mouse models with conditional TET2 deficiency [39, 40].

DNMT3A belongs to a family of cytosine methylases, which is a candidate driver gene associated with clonal hematopoiesis in the elderly with the highest mutation frequency $[6,7,14,41]$. DNMT3A deficiency is considered in playing a role in regulating proatherogenic inflammatory pathways. For example, it has been reported that DNMT3A loss of function can aggravate proinflammatory activation of mast cells[42], increase IFN (interferon)- $\gamma$ production by $\mathrm{T}$ cells [43-45], and suppress immunosuppressive function in myeloid-derived suppressor cells[46]. However, given the complex immunomodulatory properties of DNMT3A in a variety of immune cell types [42-45, 47], more experimental 
studies are needed to better understand how DNMT3A influences the pathogenesis of cardiovascular disease.

JAK2 is another common mutated gene in CHIP [6]. In one study, atherogenic effect of JAK2 mutations on mice was validated. The study demonstrated that the uptake of VLDL and LDL by macrophages was increased, which may be caused by the increase of LDL phagocytosis by bone marrow cell expansion [48]. However, neutrophil infiltration increased at the early stage of progression, and atherosclerotic plaque size increased 1.6 times compared to the control group. At the same time,inflammatory factors released by macrophages and hemophagocytosis increased and large numbers of erythrocytes and macrophages were present in the necrotic core of progressive plaque, indicating that enhanced hemophagocytosis may accelerate plaque instability [49]. In mice, red blood cells with JAK2 mutations are more likely to be eaten by macrophages [50], which suggests that JAK2 mutations may increase hemophagocytosis and accelerate artery plaque instability.

\section{CHIP-related mutations are associated with heart failure}

TET2 is an epigenetic regulatory enzyme that regulates HSPC self-renewal [39, 40, 51, 52]. Recurrent somatic TET2 mutations are gene mutations first reported in normal elderly individuals with clonal hematopoiesis [53]. Studies have shown that blood cells with TET2 mutations are associated with cardiovascular disease and early onset myocardial infarction [25]. Two groups of stress-induced heart failure mouse models were constructed. In the treatment group, TET2-deficient bone marrow was transplanted or TET2 gene was specifically knocked out in mouse bone marrow to simulate clone expansion. The results showed that TET2deficient hematopoietic cells were associated with more pronounced myocardial remodeling and impaired cardiac function in mice, characterized by higher left ventricular systolic and diastolic volumes, lower ejection fraction, and larger fibrotic regions with worsened heart failure and increased IL-1 $\beta$ signaling. NLRP3 inflammasome, a multiprotein complex, is seen as the upstream of IL- $1 \beta$, which effectively activates IL-1 $\beta$. However, when NLRP3 inflammasome inhibitor MCC950 was treated in the two groups, heart failure symptoms of TET2 deficient mice were alleviated, and the difference between the two groups was significantly reduced [35]. It is natural to think of the classic case of successful reduction of CVD targeting IL-1 $\beta$ in humans in 2017 [54]. Studies have shown that TET2 deficiency in HSPCs is associated with the risk of heart failure, possibly exacerbating heart failure through NLRP3 inflammasome and IL-1 $\beta$ pathway, which have similar inflammatory pathways to promote atherosclerosis as the previously mentioned TET2 deficiency, suggesting that NLRP3/IL-1 $\beta$ inflammatory pathway may be the significant pathway for TET2 mutations to increase cardiovascular events. Meanwhile, DNMT3A can also regulate the differentiation of hematopoietic stem cells (HSCs).DNMT3A loss of function in HSCs skews divisions toward self-renewal at the cost of differentiation. In addition, DNMT3A mutations were detected in the blood of aging individuals, suggesting that the mutant cells were more competitive than normal hematopoietic stem cells over time[55, 56]. In 2019, a study showed that patients with somatic mutations in hematopoietic cells, specifically mutations in the most common CHIP driver genes TET2 and DNMT3A, had worse long-term clinical outcomes and were associated with the development of ischemic chronic heart failure (CHF) and with poor outcomes such as death or death after rehospitalization compared with non-CHIP carriers[26].

\section{CHIP-related mutations were associated with thrombosis and myocardial injury}

Clonal hematopoietic disorders of hematopoietic system can occur in myeloproliferative tumors (MPNs), in which most MPNs have JAK2 ${ }^{\mathrm{V} 617 \mathrm{~F}}$ somatic mutations. The neutrophils with JAK2 ${ }^{\mathrm{V} 617 \mathrm{~F}}$ mutation in MPN patients increased Neutrophil extracellular traps (NET) formation, which was reduced when treated with JAK2 inhibitor Ruxolitinib. But the mechanism by which JAK2 regulates NET remains unclear. Subsequent in vivo studies on MPN mouse models showed that the JAK2 V617F mutation of neutrophils not only increased NET, but also correlated with the pre-thrombotic state. NET formation as a component of innate immunity has been thought to be related to thrombosis mechanisms [57]. Compared with JAK2 ${ }^{\mathrm{WT}}$ mice, JAK2 ${ }^{\mathrm{V} 617 \mathrm{~F}}$ mutant mice showed increased thrombosis and enhanced NET, while JAK2 inhibitor Ruxolitinib reduced thrombosis [24]. Recent studies have found that mutations in the JAK2 V617F gene occurred in normal somatic cells $[6,7]$. The researchers found that CHIP individuals with JAK2 ${ }^{\mathrm{V} 617 \mathrm{~F}}$ positive but without MPN or other hematologic malignancies were prone to thrombosis due to NET increase. Inhibition of JAK-STAT signaling with the clinically available JAK2 inhibitor ruxolitinib abolished NET formation and decreased thrombosis in a murine model of deep vein stenosis. It was shown that CHIP individuals with JAK2 ${ }^{\mathrm{V} 617 \mathrm{~F}}$ mutation were associated with a higher risk of major thrombotic events, such as venous thrombosis and pulmonary embolism, and were more likely to develop thrombotic events than those with other somatic mutations harbored CHIP [24]. This may be because JAK2 V617F mutations lead to enhanced hemophagocytosis, promoting plaque instability and accelerating atherothrombosis [50]. At the same time, the JAK2 pathway also plays an important role in immune diseases due to regulate inflammation mediators, blood coagulation and thrombosis to a large extent [58]. In another study, loss of function of TET2 
by lentiviral vector/CRISPR method caused hematopoietic cell expansion similar to previous studies. In comparison with Tet2, inactivation of Dnmt3a did not lead to detectable expansion of the mutant hematopoietic cells during the time course of these experiments[34].This finding is similar to previous reports showing that Dnmt3a-deficient HSPCs expand only in aged animals or after sequential BMT[59, 60], raising concerns about the selection of mouse models to study clonal hematopoiesis associated with mutations in DNMT3A. Further experiments provided evidence that both inactivated TET2 and DNMT3A mutations in hematopoietic cells could cause CVD. And DNMT3A and TET2 mutations alike have similar abilities to increase AngII-induced cardiac hypertrophy, impaired cardiac function, and fibrosis of the heart and kidney. In LPS-treated macrophage lines, TET2 mutation promoted the release of inflammatory cytokines IL-1, IL-6, Ccl5, while DNMT3A mutation resulted in increased expression of Cxc11, Cxcl2, IL-6 and Ccl5 [34]. Whether the myocardial injury induced by inactivated TET2 and DNMT3A is related to release of inflammation mediators remains to be further studied.

\section{Inflammatory pathways involved in the mechanism by which CHIP increases cardiovascular risk}

As mentioned above, inflammatory signaling is one of the key mechanisms by which CHIP with somatic mutations such as TET2/DNMT3A increases risk of cardiovascular events. Likely, TET2/DNMT3A mutations increase proinflammatory cytokine release, driving a feedback loop that leads to clonal expansions of mutant dominant cells, which then again amplifies deregulated and unbalanced release of pro-inflammatory cytokines [61]. Whether other CHIPrelated mutations also increase cardiovascular risk through inflammatory mechanisms is not clear. Here, the correlation between inflammatory signals and CHIP with mainly TET2/ DNMT3A mutations is discussed below.

\section{Inflammation as a consequence of clonal hematopoiesis}

Recent studies showed that mutations in TET2 and DNMT3A damaged inflammation regression and type I interferon production respectively [47, 62]. TET2 is a demethylase, but studies have shown that under LPS stimulation, TET2 regulates histone deacetylation by recruiting Hdac2 to reduce expression of cytokines IL-6 in inflammatory signaling pathways, which is independent of DNA methylation and hydroxymethylation [62].
TLR-activated NF-KB and MAPK pathways can induce pro-inflammatory cytokine expression, but this pathway is not affected in TET2-deficient bone marrow dendritic cells (BMDC) and peripheral macrophages. Compared with the control group under the same LPS-induced condition, the expression of IL-6 in TET2-deficient cells was higher; and the spontaneous TLR-signal termination pathway, which was thought to prevent excessive pro-inflammatory signals and inflammatory autoimmune disease, highlighting the important role of negative TLR regulatory signals in the stage of inflammation regression, was insufficient to weaken the expression of IL-6 in TET2-deficient cells, which also indirectly reflected the role of TET2 in inhibiting the expression of IL- 6 by promoting the regression of inflammatory responses and maintaining homeostasis[62]. IL6R P. Asp358Ala is a common variant of IL6 receptor gene that can disrupt IL-6 signaling pathway. Previous studies have found that IL6R P. Asp358Ala reduces the risk of CVD in the general population [63, 64].A recent study using LPS to treat TET2-/- macrophages found that the expression of IL- $1 \beta$ and IL- 6 increased with the extension of treatment time. At the same time, activation of Arginase $1(\operatorname{Arg} 1)$ expression which occurs normally during the TLR4 signaling phase of inflammation regression increased by 7 times in the late LPS processing. These results suggest that TET2 deficiency may impair inflammatory regression and innate immune response [65]. In 2020, Wesley T Abplanalp and his colleagues using singlecell RNA-sequencing revealed that circulating monocytes and T-cells of $\mathrm{HF}$ patients harboring $\mathrm{CH}$-driver mutations in DNMT3A exhibited a highly inflamed transcriptome in humans[66]. It has been demonstrated for the first time that DNMT3A mutation induces activation of inflammatory signals of different immune cells in humans. But DNMT3A mutations give rise to a less pronounced bias towards myeloid cells $[67,68]$. Data from animal models seems consistent with evidence from clinical trials showing that subjects with TET2 mutations have more inflammatory non-classical monocytes, while those with DNMT3A mutations have an increased Th17/Tregs ratio [69]. Jak2 VF mutations in myeloid progenitors result in monocytes and neutrophils with increased inflammatory features, causing myocardial inflammation and accelerating HF after ischemic injury [36]. Overall, these findings suggest that TET2 and JAK2 mutations could increase inflammation response, which is mediated by innate immunity; otherwise, DNTM3A mutations affect myeloid and/ or lymphoid cells.

At present, it is believed that some somatic genes with mutations can damage inflammatory regression process or activate immune response, resulting in the relative abnormal enhancement of inflammatory signals and accelerating the development of cardiovascular diseases. 


\section{Inflammation as the cause of clonal hematopoiesis}

A recent study examined the viability of TET2-KO HSPCs in the presence of inflammatory pressure. Lipopolysaccharide (LPS) is a ligand that activates toll-like receptor 4 and NF-KB signaling pathways to induce inflammatory signals in mice [70]. In LPS-treated TET2-KO mice, neutrophils, eosinophils, and basophils were significantly increased, but lymphocyte, platelet, and erythrocyte counts were approximately the same as those in wild-type mice. Surprisingly, TET2-KO hematopoietic cells had the advantage of inflammatory resistance. When treated with LPS, clonal capacity of bone marrow cells in the control group was impaired and the number of bone marrow cells was significantly reduced. However, mature bone marrow cells and HSPCs in TET2-KO mice were significantly increased and TET2-KO hematopoietic cells produced more inflammatory cytokines including IL-6. Subsequently, it was found that after LPS treatment, the expression of pro-apoptotic genes Casp1 (Encoding caspase-1) and Bcl2111 (Encoding Bim) decreased, while the expression of the genes promoting cell survival such as Bcl2 and Morrbid increased. It is possible that TET2-KO cells enhance their growth advantage under inflammatory stimulation by resisting apoptosis [71]. Morrbid is a long-stranded non-coding RNA that regulates the survival of bone marrow cells, including neutrophils, but its role in HSPCs carrying driver gene mutations is unknown [72]. In TET2-KO bone marrow cells and HSPCs, IL-6 can induce high activation of the SHp2-STAT3 signaling axis, ultimately leading to increased expression of newly discovered anti-apoptotic long-chain non-coding RNA, namely Morrbid. In TET2 mutated mice, inhibition of Shp2 or STAT3 expression with inflammatory suppressive drugs or Morrbid knockdown restored inflammatory stress-induced HSPCs and mature bone marrow cell abnormalities such as clonal hematopoiesis [71]. Therefore, under the effect of inflammatory pressure, the number of HSPCs of TET2-KO mice was increased due to resist apoptosis, and cell survival was promoted through the IL-6/Shp2/Stat3/Morrbid pathway, and finally clonal hematopoiesis was formed. A similar finding has been described that expansion of the stem/progenitor cell pool was found in CHIP patients carrying a Tet2 mutation, maybe further promoted by inflammatory conditions[38]. A new study in 2020 showed that larger CHIP clone carriers with VAF $>10 \%$ increased cardiovascular risk, accounting for the majority of the overall CHIP carrier with increased risk. This study suggested that inhibition of the IL-6 signaling pathway at the VAF $>10 \%$ CHIP population was the most effective in reducing the risk of cardiovascular disease compared with small CHIP clone carriers and non-CHIP carriers [73], but the specific mechanism needs to be clarified in the future. In another study, despite TNF- $\alpha$ inhibiting HSPCs activation, TET2-/-BM showed apoptotic resistance compared with WT in the presence of TNF- $\alpha$ for a long time. WT bone marrow cells showed that the number of clones decreased gradually with the increase of TNF- $\alpha$ dose, but the number of TET 2-/-BM clones remained at a constant level or even increased [30]. These studies indicated that the anti-apoptotic effect was enhanced and clonal hematopoiesis was promoted by the driver gene mutation in the inflammatory environment. This demonstrates that bone marrow microenvironment affects the cloning expansion of HSPCs, and improving the microenvironment can also be effective to reduce the risk of cardiovascular disease.

\section{Impact of age-related pro-inflammatory environment on HSCs fate}

We would like to further understand how inflammation influences clonal hematopoiesis formation and regulates HSCs fate, especially in the elderly population. Older individuals develop inflammatory aging, a condition characterized by elevated levels of blood inflammatory markers that carries high susceptibility to chronic morbidity, disability, frailty, and premature death, even in the absence of significant stimulation $[74,75]$. Some studies have shown that highly inflammatory environment not only promotes clonal hematopoiesis, but also controls the fate of HSCs, having a bias for inducing the proliferation of blood platelets or myeloid cells in HSCs differentiation, and increasing the risk of cardiovascular diseases by leukocytes migrating into the arterial intima and the expansion of neutrophils within the plaque leading to plaque rupture [76]. Chronic inflammation in old age, although resistant to pathogen invasion, has adverse effects on human health and is associated with the development of multiple diseases due to impaired immune responses, including heart disease[77]. At the same time, older humans and aging animals such as mice exhibit significant changes in blood systems, with reduced HSCs activity lymphocyte generation, and a tendency to myeloid cells production, and higher levels of inflammatory cytokines [78, 79], which may have close relationship with the risk of cardiovascular disease. HSCs maintain lifelong blood production and increase blood cell numbers in response to chronic and acute injury. Recent studies have shown that in young mice, only a small fraction of HSCs was IL-27Ra ${ }^{+}$, which plays an essential role in myeloid recovery following microbial invasion. But in old age, HSCs of IL-27Ra ${ }^{+}$are abundant, and the upregulated TNF $\alpha$-ERk-ETS1 pathway increases IL-27Ra ${ }^{+}$ gene transcription,promoting the proliferation of myeloid cells, inflammatory phenotypes, and the reduction of the potential of HSCs [80]. Current research reveals that bone marrow microenvironments such as chronic inflammation state could influence the fate of HSCs [78]. Meanwhile, 
the aging of bone marrow microenvironment is associated with the increased pro-inflammatory cytokines varieties, both in mice and humans[81].

Inflammatory signals may have different effects on HSCs differentiation. Several pieces of evidence suggest that inflammatory cytokines drive differentiation of myeloid/megakaryocytes. For instance, IFN $\gamma$ induces myeloid differentiation through activating the transcription factors Batf2 and C/EBP $\beta[82,83]$. Pietras et al. reported that interleukin-1 (IL-1), which functions as a key proinflammatory 'emergency' signal, directly accelerating cell division and myeloid differentiation of HSCs through NF- $\kappa B-d e p e n d e n t ~ P U .1$ activation [84]. IL- $1 \alpha / \beta$ regulates thrombopoiesis in vitro $[85,86]$, possibly the reason of high platelet counts in aged mice [87]. Defective phagocytosis of macrophages during aging induces expansion of platelet-biased HSCs through Il- $1 \beta$ signaling [88], which may be one of the mechanisms of arterial plaque thrombosis. IFN-1 $\mathrm{s}$ and TNF promote megakaryocytopoiesis in a subset of HSC-like cells highly expressing the megakaryocyte marker CD41 through post-transcriptional program [89]. Chronic IL-1 stimulation can also induce similar expansion of CD $41^{\text {hi }}$ cells, suggesting possibly a common mechanism for inducing platelet generation that drives inflammatory thrombogenesis[84, 89]. Noticeably, IFN-1 can induce HSCs differentiation only restricted in $\mathrm{CD} 41^{\text {hi }}$ expressing cells, suggesting HSCs respond to different inflammatory signals in a heterogenous manner [89]. In the future, it will be necessary to investigate whether other inflammatory factors also act specifically on CD41 expressing cells. The role of these mechanisms in complex diseases such as cardiovascular disease needs to be further studied.

Inflammatory signaling also has a negative impact on HSCs' ability to self-renew. Chronic IL-1 exposure restricts HSCs lineage output, severely decaying HSCs self-renewal capacity. Importantly, these destructive effects are transient and fully reversible on IL-1 removal [84]. Takizawa et al. reported that in vivo lipopolysaccharide (LPS) application makes proliferation of dormant HSCs directly via TLR4 and that persistent LPS exposure damages HSCs self-renewal and competitive repopulation activity[90]. But how impaired HSCs self-renewal manifests in human diseases has been little studied. In vivo microenvironment of the elderly is in an inflammatory state for a long time, leading to changes in the differentiation direction and self-renewal function of HSCs, which may be one of the links between CHIP and cardiovascular disease. But whether inflammation tends to have a more pronounced effect on mutated HSCs is unclear. It requires further research about whether non-mutated HSPCs are also affected in individuals with CHIP caused by TET2 mutations through a paracrine, cell-extrinsic fashion such as an inflammatory milieu [38].

\section{Prospects for targeting CHIP-related mutations}

A large number of studies have shown that inflammation plays an important role in the aggravation of cardiovascular disease caused by mutations such as TET2/DNMT3A. Based on the above, we have learned that using NLRP3 inhibitors or targeting IL-1, IL-6 can effectively attenuate heart damage caused by TET 2 mutation. In addition, targeting related mutations may be another strategy for reversing or mitigating the development of cardiovascular disease.

\section{Vitamin C to restore for TET2 Function}

The key function of TET2 is to regulate HSPCs self-renewal and proliferation, and the absence of TET2 will cause abnormal HSPCs self-renewal and bone marrow expansion [40, 91]. However, there are few therapeutic options for targeting TET2 activation. In a recent study, Cimmino et al. treated mice with reversible transgenic RNA to form a TET2 recovery model, interestingly, which could restore the abnormal self-renewal of HSPC. This study suggests that TET2 reactivation may be a therapeutic target for patients with clonal hematopoiesis such as myelodysplastic syndrome and myeloid leukemia by promoting DNA demethylation. Meanwhile, recovery and activation of TET 2 can reverse the abnormal self-renewal of HSPCs in vitro and in vivo [92].Vitamin $\mathrm{C}$, a $\mathrm{Fe} 2+$ and $\alpha-\mathrm{Kg}$ dependent dioxygenase cofactor, simulates TET 2 recovery by promoting 5-hydroxymethylcytosine formation in HSPCs of TET2-deficient mice. It can inhibit the clone formation of leukemia cells and delay the development of leukemia [92]. Similarly, Cimmino and colleagues treated mouse HSPCs and human leukemia cells with vitamin $\mathrm{C}$. They found that vitamin $\mathrm{C}$ simulated the activation of TET2 in HSPCs of TET2-deficient mice and increased 5-hydroxymethylpyrimethine (5HMC) formation [93], consistent with previous studies. The above studies support the use of vitamin $\mathrm{C}$ in the treatment of $\mathrm{AML}$ patients harboring TET2 mutations, but the need for sufficient vitamin $\mathrm{C}$ to achieve normal TET2 levels is a challenge for clinical treatment of patients. In several recent studies, vitamin C (ascorbate) was used clinically in patients harboring TET2 mutations, where TET2 was activated and survival was increased in older patients with AML(Acute Myelocytic Leukemia), although TET2 deficiency induced clone was reproduced when the disease relapsed [94, 95]. There has been little research on targeting TET2 for cardiovascular diseases, but targeting TET2 for tumor prevention and treatment is the first step in the clinical treatment of cardiovascular diseases. 


\section{JAK2 Inhibitors}

In 2018, a study showed that JAK2 inhibitor Ruxolitinib can reduce thrombosis by decreased Neutrophil extracellular traps (NET) formation which was induced by JAK2 V617F mutation in MPN patients [24]. Xilan Yang et al. found that Ruxolitinib, an inhibitor of the Janus kinase 2 (JAK2), substantially reduced area of atherosclerotic plaques in rabbits treated with high fat diet [96] Furthermore, it has been shown that the selective Jak2 inhibition with fedratinib reduces the formation of atherosclerotic plaque by suppressing excessive myelopoiesis in Apoe-/-mice[97]. More interestingly, Haojie Jiang and collaborators found that JAK2 V617F mutations dramatically increased the binding of AGK (Acylglycerol kinase) to JAK2 and significantly facilitated JAK2/Stat3 signaling in megakaryocytes/platelets in response to thrombopoietin[98]. Collectively, these findings suggest that inhibition of JAK2 or targeting the interaction between AGK and JAK2 may alleviate thrombotic CVD in CHIP patients carrying JAK2 mutations.

\section{Lower blood glucose}

CHIP carriers display a 30\% increased risk of type 2 diabetes[25], a risk factor for both CVD and cancer[99]. Increased glucose levels impede AMPK-mediated phosphorylation at serine 99, which results in the destabilization of TET2. Treatment with the anti-diabetic drug metformin protects AMPK-mediated phosphorylation of serine 99, thereby rescuing TET2 stability and $5 \mathrm{hmC}$ levels [100]. The above studies suggest that high-level glucose may accelerate the mutation of TET2, while tight control of glucose to maintain the stability of TET2 can have a protective effect on cardiovascular system in patients carrying TET2-driven CHIP.

\section{Conclusion and future directions}

Cardiovascular disease is the leading cause of death worldwide and is becoming more common with age. Despite strong epidemiological evidence linking cardiovascular disease to aging [101], how aging affects the development of cardiovascular disease is unclear. Clonal hematopoiesis is an inevitable result of normal aging in human beings. Clinical studies have shown that clonal hematopoiesis is associated with increased mortality and cancer $[6,7,14,25,26$,
102]. In particular, all-cause mortality and cardiovascular events increased in CHIP carriers, while TET2, DNMT3A and JAK2 were the most common mutated genes in hematopoietic cells of CHIP individuals, leading to pathological changes in the mouse model of atherosclerosis or heart failure Fig. 1 [25, 33-36]. Nowadays, a few studies have shown that CHIP produced by unknown driver genes also increases cardiovascular risk and all-cause mortality $[7,13,14,73]$. Other heart diseases related driver genes need to be explored in the future. Through these studies, we found that cardiovascular events caused by CHIP harboring JAK2 mutations were associated with increased neutrophils extracellular traps, different from increased pro-inflammatory regulatory factor expression by TET2 mutations. At the same time, there was no change in platelet count in TET2-deficient mice. This suggests that different mutations may act on specific diseases through different pathways, and further studies are needed to better target disease-specific mutations in the future.

Our understanding of the link between CHIP and CVD is incomplete. Yet based on previous studies on TET2 mutations Table 1, we found that inflammation may be one of the main mechanisms of CHIP increasing CVD, especially cytokines such as IL-1 $\beta$ and IL-6. Inhibition of IL-6 factor could effectively reduce the risk of cardiovascular events for CHIP carriers with VAF greater than $10 \%$, while having little effect on small clones. [73]. So here we have proposed two hypotheses about the mechanisms of inflammatory regulation. One hypothesis is that somatic gene mutations accumulate with age, and the gene itself has the effects of preventing excessive inflammation or maintaining organism homeostasis. However, mutations lead to excessive inflammatory signals response such as increased expression of IL-6, which can accelerate the development of cardiovascular diseases. Another hypothesis is that under bone marrow microenvironment with an inflammatory state, HSPCs with driver gene mutations have a phenotype resistant to apoptosis, while the clone number of cells without mutations is reduced. As the clone expansion of surviving HSPCs with mutations (such as TET2 mutations) is enhanced, HSPCs pool may be enlarged. Based on these two hypotheses, inflammation and mutations/CH may form a feedback loop in aging individuals, reinforcing each other to maintain a long-term inflammatory internal environment. Inflammatory environment also affects the differentiation and self-renewal 


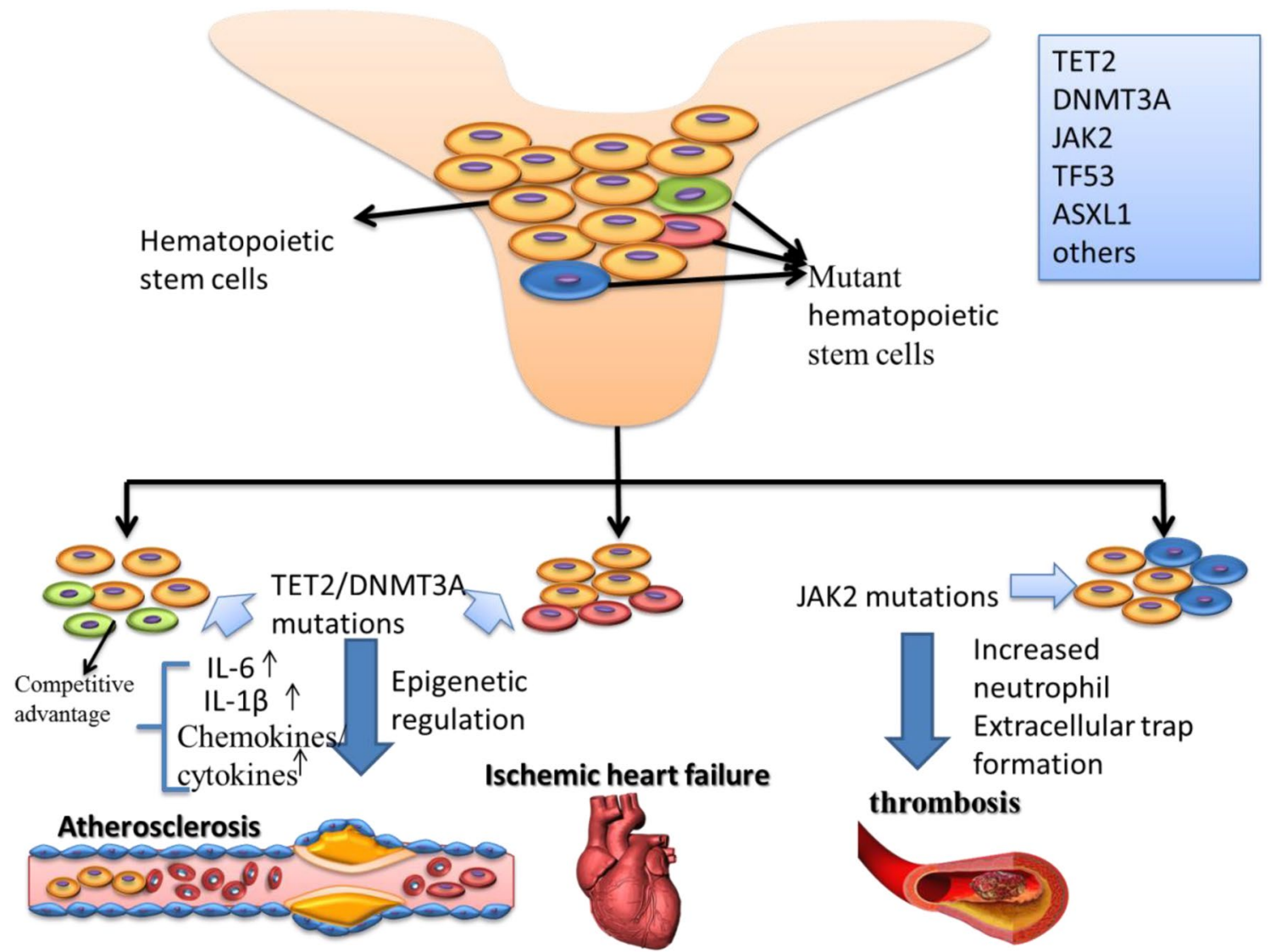

Fig. 1 Possible pathways associated with clonal hematopoiesis increasing the risk of cardiovascular disease. Genetic mutations accumulate with age. Among them, the common mutated genes are TET2, DNMT3A, JAK2, and a few mutations confer the cells competitive advantage and form clonal hematopoiesis. Recent studies have shown that individuals with clonal hematopoiesis have an increased risk of cardiovascular disease $[6,25]$. Subsequent studies have found that

ability of HSCs. Chronic inflammation associated with aging damages the potential of HSCs and immune function, and adversely affects the hematopoietic system. It is not clear whether inflammatory signaling is also a crucial regulatory factor in the relationship between clonal hematopoiesis and aging, but the effect of chronic aging-inflammation on HSCs is highly likely associated with cardiovascular disease and immune respond. This is why the elderly have a high prevalence rate and are the most vulnerable from COVID-19.
TET2 and DNMT3A mutations increase the expression of inflammasome and cytokines IL- $1 \beta$ and IL- 6 , which can promote the development of cardiovascular diseases such as atherosclerosis and heart failure[26, 33, 35], while JAK2 mutations can accelerate plaque instability by increasing hemophagocytosis and promote thrombosis by increasing the effect of NETs[24, 50]

Cardiovascular disease remains the leading cause of death worldwide, but a significant proportion of elderly cardiovascular patients do not have the traditional risk factors forCVD. Therefore, targeting inflammatory mediators or associated mutated genes may provide new strategies for treating cardiovascular diseases. At the same time with the better understanding of CHIP, therapeutic armamentarium to prevent its detrimental effects should also emerge. 
Table 1 The role of inflammatory pathways in TET2-mutated CHIP increasing cardiovascular risk

\begin{tabular}{|c|c|c|c|}
\hline Author & Main pathways & Main findings & References \\
\hline \multicolumn{4}{|c|}{ Inflammation as a consequence of clonal hematopoiesis related gene mutatons } \\
\hline Zhang Q, et al & $\begin{array}{l}\text { reducion in TET } 2 \text { regulateing histone deacetylation by } \\
\text { recruiting Hdac2 }\end{array}$ & Increasing expression of cytokines IL-6 & {$[62]$} \\
\hline Cull AH, et al & $\begin{array}{l}\text { TET } 2 \text { mutation increasing the level of Arginase } 1 \\
\text { (Arg1) by seven times }\end{array}$ & $\begin{array}{l}\text { Impairing inflammatory regression and innate } \\
\text { immune response }\end{array}$ & {$[65]$} \\
\hline \multicolumn{4}{|c|}{ Inflammation as the cause of clonal hematopoiesis formation } \\
\hline Cai Z, et al & $\begin{array}{l}\text { Under LPS treatment,TET2 mutations promoting cell } \\
\text { survival by IL6/SHp2-STAT3/Morrbid pathway }\end{array}$ & $\begin{array}{l}\text { Enhanced apoptotic resistance and clonal hemapotosis } \\
\text { formation }\end{array}$ & [71] \\
\hline Abegunde SO, et al & $\begin{array}{l}\text { TNF- } \alpha \text { treatment decreasing mRNA levels of pro- } \\
\text { apoptotic targets Tnfrsf1a,Tnfrsf1b, Fas, Casp3 and } \\
\text { Casp8 }\end{array}$ & $\begin{array}{l}\text { Apoptotic resistance and clonal hemapotosis forma- } \\
\text { tion in TET2-/-BM compared to WT-BM }\end{array}$ & {$[30]$} \\
\hline \multicolumn{4}{|c|}{ The crucial role of inflammation at the increased risk for cardiovascular disease in CHIP individuals } \\
\hline Bick AG, et al & $\begin{array}{l}\text { IL- } 6 \text { signaling pathway at the VAF }>10 \% \text { CHIP } \\
\text { population }\end{array}$ & $\begin{array}{l}\text { Decreased risk of cardiovascular disease in inhibit- } \\
\text { ing IL-6 signaling pathway at the VAF }>10 \% \text { CHIP } \\
\text { population }\end{array}$ & [73] \\
\hline Fuster JJ, et al & NLRP3 inflammasome/IL $-1 \beta$ pathway & Accelerating atherogenesis and plaque expansion & [33] \\
\hline Sano $S$, et al & NLRP3 inflammasome/IL - $1 \beta$ pathway & Aggravating in heart failure & [35] \\
\hline
\end{tabular}

Acknowledgements This work was supported by grants from the National Natural Science Foundation of China (81672084).

\section{Declarations}

Conflict of interest The authors do not have any conflicts of interest to declare.

\section{References}

1. Martincorena I, Campbell PJ (2015) Somatic mutation in cancer and normal cells. Science 349:1483-1489

2. Blokzijl F, de Ligt J, Jager M, Sasselli V, Roerink S, Sasaki N, Huch M, Boymans S, Kuijk E, Prins P, Nijman IJ, Martincorena I, Mokry M, Wiegerinck CL, Middendorp S, Sato T, Schwank G, Nieuwenhuis EE, Verstegen MM, van der Laan LJ, de Jonge J, IJzermans JN, Vries RG, van de Wetering M, Stratton MR, Clevers H, Cuppen E, van Boxtel R (2016) Tissue-specific mutation accumulation in human adult stem cells during life. Nature 538:260-264

3. Yizhak K, Aguet F, Kim J, Hess JM, Kubler K, Grimsby J, Frazer R, Zhang H, Haradhvala NJ, Rosebrock D, Livitz D, Li X, ArichLandkof E, Shoresh N, Stewart C, Segre AV, Branton PA, Polak P, Ardlie KG, Getz G (2019) Rna sequence analysis reveals macroscopic somatic clonal expansion across normal tissues. Science 364(6444):e0762

4. Jaiswal S, Ebert BL (2019) Clonal hematopoiesis in human aging and disease. Science 366(6465):e4673

5. Bowman RL, Busque L, Levine RL (2018) Clonal hematopoiesis and evolution to hematopoietic malignancies. Cell Stem Cell 22:157-170

6. Jaiswal S, Fontanillas P, Flannick J, Manning A, Grauman PV, Mar BG, Lindsley RC, Mermel CH, Burtt N, Chavez A, Higgins JM, Moltchanov V, Kuo FC, Kluk MJ, Henderson B, Kinnunen L, Koistinen HA, Ladenvall C, Getz G, Correa A,
Banahan BF, Gabriel S, Kathiresan S, Stringham HM, McCarthy MI, Boehnke M, Tuomilehto J, Haiman C, Groop L, Atzmon G, Wilson JG, Neuberg D, Altshuler D, Ebert BL (2014) Age-related clonal hematopoiesis associated with adverse outcomes. N Engl J Med 371:2488-2498

7. Genovese G, Kahler AK, Handsaker RE, Lindberg J, Rose SA, Bakhoum SF, Chambert K, Mick E, Neale BM, Fromer M, Purcell SM, Svantesson O, Landen M, Hoglund M, Lehmann S, Gabriel SB, Moran JL, Lander ES, Sullivan PF, Sklar P, Gronberg H, Hultman CM, McCarroll SA (2014) Clonal hematopoiesis and blood-cancer risk inferred from blood DNA sequence. N Engl J Med 371:2477-2487

8. Steensma DP, Bejar R, Jaiswal S, Lindsley RC, Sekeres MA, Hasserjian RP, Ebert BL (2015) Clonal hematopoiesis of indeterminate potential and its distinction from myelodysplastic syndromes. Blood 126:9-16

9. Steensma DP (2018) Clinical consequences of clonal hematopoiesis of indeterminate potential. Hematology Am Soc Hematol Educ Program 2018:264-269

10. Zink F, Stacey SN, Norddahl GL, Frigge ML, Magnusson OT, Jonsdottir I, Thorgeirsson TE, Sigurdsson A, Gudjonsson SA, Gudmundsson J (2017) Clonal hematopoiesis, with and without candidate driver mutations, is common in the elderly. Blood 130:742-752

11. Young AL, Challen GA, Birmann BM, Druley TE (2016) Clonal haematopoiesis harbouring aml-associated mutations is ubiquitous in healthy adults. Nat Commun 7:12484

12. Shlush LI (2018) Age-related clonal hematopoiesis. Blood 131:496-504

13. Loh PR, Genovese G, Handsaker RE, Finucane HK, Reshef YA, Palamara PF, Birmann BM, Talkowski ME, Bakhoum SF, McCarroll SA, Price AL (2018) Insights into clonal haematopoiesis from 8,342 mosaic chromosomal alterations. Nature 559:350-355

14. Zink F, Stacey SN, Norddahl GL, Frigge ML, Magnusson OT, Jonsdottir I, Thorgeirsson TE, Sigurdsson A, Gudjonsson SA, Gudmundsson J, Jonasson JG, Tryggvadottir L, Jonsson T, Helgason A, Gylfason A, Sulem P, Rafnar T, Thorsteinsdottir 
U, Gudbjartsson DF, Masson G, Kong A, Stefansson K (2017) Clonal hematopoiesis, with and without candidate driver mutations, is common in the elderly. Blood 130:742-752

15. Abdel-Wahab O, Gao J, Adli M, Dey A, Trimarchi T, Chung YR, Kuscu C, Hricik T, Ndiaye-Lobry D, Lafave LM, Koche R, Shih AH, Guryanova OA, Kim E, Li S, Pandey S, Shin JY, Telis L, Liu J, Bhatt PK, Monette S, Zhao X, Mason CE, Park CY, Bernstein BE, Aifantis I, Levine RL (2013) Deletion of asxl1 results in myelodysplasia and severe developmental defects in vivo. J Exp Med 210:2641-2659

16. Duncan BK, Miller JH (1980) Mutagenic deamination of cytosine residues in DNA. Nature 287:560-561

17. Alexandrov LB, NikZainal S, Wedge DC, Aparicio SA, Behjati S, Biankin AV, Bignell GR, Bolli N, Borg A, BorresenDale AL, Boyault S, Burkhardt B, Butler AP, Caldas C, Davies HR, Desmedt C, Eils R, Eyfjord JE, Foekens JA, Greaves M, Hosoda F, Hutter B, Ilicic T, Imbeaud S, Imielinski M, Jager N, Jones DT, Jones D, Knappskog S, Kool M, Lakhani SR, LopezOtin C, Martin S, Munshi NC, Nakamura H, Northcott PA, Pajic M, Papaemmanuil E, Paradiso A, Pearson JV, Puente XS, Raine K, Ramakrishna M, Richardson AL, Richter J, Rosenstiel P, Schlesner M, Schumacher TN, Span PN, Teague JW, Totoki Y, Tutt AN, ValdesMas R, van Buuren MM, van Veer LT, VincentSalomon A, Waddell N, Yates LR, Australian Pancreatic CancerGenome I, Consortium IBC, Consortium IMS, PedBrain I, Zucman-Rossi J, Futreal PA, McDermott U, Lichter P, Meyerson M, Grimmond SM, Siebert R, Campo E, Shibata T, Pfister SM, Campbell PJ (2013) Stratton MR. Signatures of mutational processes in human cancer. Nature 500:415-421

18. Rodgers K, McVey M (2016) Error-prone repair of DNA doublestrand breaks. J Cell Physiol 231:15-24

19. Beerman I, Seita J, Inlay MA, Weissman IL, Rossi DJ (2014) Quiescent hematopoietic stem cells accumulate DNA damage during aging that is repaired upon entry into cell cycle. Cell Stem Cell 15:37-50

20. Kunkel TA (2004) DNA replication fidelity. J Biol Chem 279:16895-16898

21. Sanders MA, Chew E, Flensburg C, Zeilemaker A, Miller SE, Al Hinai AS, Bajel A, Luiken B, Rijken M, McLennan T, Hoogenboezem RM, Kavelaars FG, Frohling S, Blewitt ME, Bindels EM, Alexander WS, Lowenberg B, Roberts AW, Valk PJM, Majewski IJ (2018) Mbd4 guards against methylation damage and germ line deficiency predisposes to clonal hematopoiesis and early-onset aml. Blood 132:1526-1534

22. Tomasetti C, Vogelstein B (2015) Cancer etiology. Variation in cancer risk among tissues can be explained by the number of stem cell divisions. Science 347:78-8

23. Laurie CC, Laurie CA, Rice K, Doheny KF, Zelnick LR, McHugh CP, Ling H, Hetrick KN, Pugh EW, Amos C, Wei Q, Wang LE, Lee JE, Barnes KC, Hansel NN, Mathias R, Daley D, Beaty TH, Scott AF, Ruczinski I, Scharpf RB, Bierut LJ, Hartz SM, Landi MT, Freedman ND, Goldin LR, Ginsburg D, Li J, Desch KC, Strom SS, Blot WJ, Signorello LB, Ingles SA, Chanock SJ, Berndt SI, Le Marchand L, Henderson BE, Monroe KR, Heit JA, de Andrade M, Armasu SM, Regnier C, Lowe WL, Hayes MG, Marazita ML, Feingold E, Murray JC, Melbye M, Feenstra B, Kang JH, Wiggs JL, Jarvik GP, McDavid AN, Seshan VE, Mirel DB, Crenshaw A, Sharopova N, Wise A, Shen J, Crosslin DR, Levine DM, Zheng X, Udren JI, Bennett S, Nelson SC, Gogarten SM, Conomos MP, Heagerty P, Manolio T, Pasquale LR, Haiman CA, Caporaso N, Weir BS (2012) Detectable clonal mosaicism from birth to old age and its relationship to cancer. Nat Genet 44:642-650

24. Wolach O, Sellar RS, Martinod K, Cherpokova D, McConkey M, Chappell RJ, Silver AJ, Adams D, Castellano CA, Schneider RK,
Padera RF, DeAngelo DJ, Wadleigh M, Steensma DP, Galinsky I, Stone RM, Genovese G, McCarroll SA, Iliadou B, Hultman C, Neuberg D, Mullally A, Wagner DD, Ebert BL (2018) Increased neutrophil extracellular trap formation promotes thrombosis in myeloproliferative neoplasms. Sci Transl Med 10(436):e8292

25. Jaiswal S, Natarajan P, Silver AJ, Gibson CJ, Bick AG, Shvartz E, McConkey M, Gupta N, Gabriel S, Ardissino D, Baber U, Mehran R, Fuster V, Danesh J, Frossard P, Saleheen D, Melander O, Sukhova GK, Neuberg D, Libby P, Kathiresan S, Ebert BL (2017) Clonal hematopoiesis and risk of atherosclerotic cardiovascular disease. N Engl J Med 377:111-121

26. Dorsheimer L, Assmus B, Rasper T, Ortmann CA, Ecke A, Abou-El-Ardat K, Schmid T, Brune B, Wagner S, Serve H, Hoffmann J, Seeger F, Dimmeler S, Zeiher AM, Rieger MA (2019) Association of mutations contributing to clonal hematopoiesis with prognosis in chronic ischemic heart failure. JAMA Cardiol $4: 25-33$

27. Abplanalp WT, Cremer S, John D, Hoffmann J, Schuhmacher B, Merten M, Rieger MA, Vasa-Nicotera M, Zeiher AM, Dimmeler S (2021) Clonal hematopoiesis-driver dnmt3a mutations alter immune cells in heart failure. Circ Res 128:216-228

28. Ebert BL, Libby P (2018) Clonal hematopoiesis confers predisposition to both cardiovascular disease and cancer: A newly recognized link between two major killers. Ann Intern Med 169:116-117

29. Bonnefond A, Skrobek B, Lobbens S, Eury E, Thuillier D, Cauchi S, Lantieri O, Balkau B, Riboli E, Marre M, Charpentier G, Yengo L, Froguel P (2013) Association between large detectable clonal mosaicism and type 2 diabetes with vascular complications. Nat Genet 45:1040-1043

30. Abegunde SO, Buckstein R, Wells RA, Rauh MJ (2018) An inflammatory environment containing tnfalpha favors tet2-mutant clonal hematopoiesis. Exp Hematol 59:60-65

31. Meisel M, Hinterleitner R, Pacis A, Chen L, Earley ZM, Mayassi T, Pierre JF, Ernest JD, Galipeau HJ, Thuille N, Bouziat R, Buscarlet M, Ringus DL, Wang Y, Li Y, Dinh V, Kim SM, McDonald BD, Zurenski MA, Musch MW, Furtado GC, Lira SA, Baier G, Chang EB, Eren AM, Weber CR, Busque L, Godley LA, Verdu EF, Barreiro LB, Jabri B (2018) Microbial signals drive preleukaemic myeloproliferation in a tet2-deficient host. Nature 557:580-584

32. Hasselbalch HC (2012) Perspectives on chronic inflammation in essential thrombocythemia, polycythemia vera, and myelofibrosis: Is chronic inflammation a trigger and driver of clonal evolution and development of accelerated atherosclerosis and second cancer? Blood 119:3219-3225

33. Fuster JJ, MacLauchlan S, Zuriaga MA, Polackal MN, Ostriker AC, Chakraborty R, Wu CL, Sano S, Muralidharan S, Rius C, Vuong J, Jacob S, Muralidhar V, Robertson AA, Cooper MA, Andres V, Hirschi KK, Martin KA, Walsh K (2017) Clonal hematopoiesis associated with tet2 deficiency accelerates atherosclerosis development in mice. Science 355:842-847

34. Sano S, Oshima K, Wang Y, Katanasaka Y, Sano M, Walsh K (2018) Crispr-mediated gene editing to assess the roles of tet2 and dnmt3a in clonal hematopoiesis and cardiovascular disease. Circ Res 123:335-341

35. Sano S, Oshima K, Wang Y, MacLauchlan S, Katanasaka Y, Sano M, Zuriaga MA, Yoshiyama M, Goukassian D, Cooper MA, Fuster JJ, Walsh K (2018) Tet2-mediated clonal hematopoiesis accelerates heart failure through a mechanism involving the il-1beta/nlrp3 inflammasome. J Am Coll Cardiol 71:875-886

36. Sano S, Wang Y, Yura Y, Sano M, Oshima K, Yang Y, Katanasaka Y, Min KD, Matsuura S, Ravid K, Mohi G, Walsh K (2019) Jak2 (v617f) -mediated clonal hematopoiesis accelerates 
pathological remodeling in murine heart failure. JACC Basic Transl Sci 4:684-697

37. Libby P (2017) Interleukin-1 beta as a target for atherosclerosis therapy: Biological basis of cantos and beyond. J Am Coll Cardiol 70:2278-2289

38. Dorsheimer L, Assmus B, Rasper T, Ortmann CA, Abou-ElArdat K, Kiefer KC, Hoffmann J, Seeger F, Bonig H, Dimmeler S, Zeiher AM, Rieger MA (2020) Hematopoietic alterations in chronic heart failure patients by somatic mutations leading to clonal hematopoiesis. Haematologica 105:e328-e332

39. Moran-Crusio K, Reavie L, Shih A, Abdel-Wahab O, NdiayeLobry D, Lobry C, Figueroa ME, Vasanthakumar A, Patel J, Zhao X, Perna F, Pandey S, Madzo J, Song C, Dai Q, He C, Ibrahim S, Beran M, Zavadil J, Nimer SD, Melnick A, Godley LA, Aifantis I, Levine RL (2011) Tet2 loss leads to increased hematopoietic stem cell self-renewal and myeloid transformation. Cancer Cell 20:11-24

40. Ko M, Bandukwala HS, An J, Lamperti ED, Thompson EC, Hastie R, Tsangaratou A, Rajewsky K, Koralov SB, Rao A (2011) Ten-eleven-translocation 2 (tet2) negatively regulates homeostasis and differentiation of hematopoietic stem cells in mice. Proc Natl Acad Sci U S A 108:14566-14571

41. Xie M, Lu C, Wang J, McLellan MD, Johnson KJ, Wendl MC, McMichael JF, Schmidt HK, Yellapantula V, Miller CA, Ozenberger BA, Welch JS, Link DC, Walter MJ, Mardis ER, Dipersio JF, Chen F, Wilson RK, Ley TJ, Ding L (2014) Age-related mutations associated with clonal hematopoietic expansion and malignancies. Nat Med 20:1472-1478

42. Leoni C, Montagner S, Rinaldi A, Bertoni F, Polletti S, Balestrieri C, Monticelli S (2017) Dnmt3a restrains mast cell inflammatory responses. Proc Natl Acad Sci U S A 114:E1490-E1499

43. Gamper CJ, Agoston AT, Nelson WG, Powell JD (2009) Identification of DNA methyltransferase $3 \mathrm{a}$ as a t cell receptorinduced regulator of th1 and th2 differentiation. J Immunol 183:2267-2276

44. Pham D, Yu Q, Walline CC, Muthukrishnan R, Blum JS, Kaplan MH (2013) Opposing roles of stat 4 and dnmt3a in th1 gene regulation. J Immunol 191:902-911

45. Yu Q, Zhou B, Zhang Y, Nguyen ET, Du J, Glosson NL, Kaplan MH (2012) DNA methyltransferase 3a limits the expression of interleukin-13 in thelper 2 cells and allergic airway inflammation. Proc Natl Acad Sci U S A 109:541-546

46. Rodriguez-Ubreva J, Catala-Moll F, Obermajer N, AlvarezErrico D, Ramirez RN, Company C, Vento-Tormo R, MorenoBueno G, Edwards RP, Mortazavi A, Kalinski P, Ballestar E (2017) Prostaglandin e2 leads to the acquisition of dnmt3adependent tolerogenic functions in human myeloid-derived suppressor cells. Cell Rep 21:154-167

47. Li X, Zhang Q, Ding Y, Liu Y, Zhao D, Zhao K, Shen Q, Liu X, Zhu X, Li N, Cheng Z, Fan G, Wang Q, Cao X (2016) Methyltransferase dnmt3a upregulates hdac 9 to deacetylate the kinase tbk1 for activation of antiviral innate immunity. Nat Immunol $17: 806-815$

48. Ginsberg H, Gilbert HS, Gibson JC, Le NA, Brown WV (1982) Increased low-density-lipoprotein catabolism in myeloproliferative disorders. Ann Intern Med 96:311-316

49. Kolodgie FD, Gold HK, Burke AP, Fowler DR, Kruth HS, Weber DK, Farb A, Guerrero LJ, Hayase M, Kutys R, Narula J, Finn AV, Virmani R (2003) Intraplaque hemorrhage and progression of coronary atheroma. N Engl J Med 349:2316-2325

50. Wang W, Liu W, Fidler T, Wang Y, Tang Y, Woods B, Welch C, Cai B, Silvestre-Roig C, Ai D, Yang YG, Hidalgo A, Soehnlein O, Tabas I, Levine RL, Tall AR, Wang N (2018) Macrophage inflammation, erythrophagocytosis, and accelerated atherosclerosis in jak2 (v617f) mice. Circ Res 123:e35-e47
51. Quivoron C, Couronne L, Della Valle V, Lopez CK, Plo I, Wagner-Ballon O, Do Cruzeiro M, Delhommeau F, Arnulf B, Stern MH, Godley L, Opolon P, Tilly H, Solary E, Duffourd Y, Dessen P, Merle-Beral H, Nguyen-Khac F, Fontenay M, Vainchenker W, Bastard C, Mercher T, Bernard OA (2011) Tet2 inactivation results in pleiotropic hematopoietic abnormalities in mouse and is a recurrent event during human lymphomagenesis. Cancer Cell $20: 25-38$

52. Li Z, Cai X, Cai CL, Wang J, Zhang W, Petersen BE, Yang FC, Xu M (2011) Deletion of tet2 in mice leads to dysregulated hematopoietic stem cells and subsequent development of myeloid malignancies. Blood 118:4509-4518

53. Busque L, Patel JP, Figueroa ME, Vasanthakumar A, Provost S, Hamilou Z, Mollica L, Li J, Viale A, Heguy A, Hassimi M, Socci N, Bhatt PK, Gonen M, Mason CE, Melnick A, Godley LA, Brennan CW, Abdel-Wahab O, Levine RL (2012) Recurrent somatic tet 2 mutations in normal elderly individuals with clonal hematopoiesis. Nat Genet 44:1179-1181

54. Ridker PM, Everett BM, Thuren T, MacFadyen JG, Chang WH, Ballantyne C, Fonseca F, Nicolau J, Koenig W, Anker SD, Kastelein JJP, Cornel JH, Pais P, Pella D, Genest J, Cifkova R, Lorenzatti A, Forster T, Kobalava Z, Vida-Simiti L, Flather M, Shimokawa H, Ogawa H, Dellborg M, Rossi PRF, Troquay RPT, Libby P, Glynn RJ, Group CT (2017) Antiinflammatory therapy with canakinumab for atherosclerotic disease. N Engl J Med 377:1119-1131

55. Jeong M, Park HJ, Celik H, Ostrander EL, Reyes JM, Guzman A, Rodriguez B, Lei Y, Lee Y, Ding L, Guryanova OA, Li W, Goodell MA, Challen GA (2018) Loss of dnmt3a immortalizes hematopoietic stem cells in vivo. Cell Rep 23:1-10

56. Yang L, Rau R, Goodell MA (2015) Dnmt3a in haematological malignancies. Nat Rev Cancer 15:152-165

57. Barnado A, Crofford LJ, Oates JC (2016) At the bedside: Neutrophil extracellular traps (nets) as targets for biomarkers and therapies in autoimmune diseases. J Leukoc Biol 99:265-278

58 Perner F, Perner C, Ernst T, Heidel FH (2019) Roles of jak2 in aging, inflammation, hematopoiesis and malignant transformation. Cells 8(8):e854

59. Challen GA, Sun D, Jeong M, Luo M, Jelinek J, Berg JS, Bock C, Vasanthakumar A, Gu H, Xi Y, Liang S, Lu Y, Darlington GJ, Meissner A, Issa JP, Godley LA, Li W, Goodell MA (2011) Dnmt3a is essential for hematopoietic stem cell differentiation. Nat Genet 44:23-31

60. Zhang X, Su J, Jeong M, Ko M, Huang Y, Park HJ, Guzman A, Lei Y, Huang YH, Rao A, Li W, Goodell MA (2016) Dnmt3a and tet 2 compete and cooperate to repress lineage-specific transcription factors in hematopoietic stem cells. Nat Genet 48:1014-1023

61. Papa V, Marracino L, Fortini F, Rizzo P, Campo G, Vaccarezza M, Sega Vieceli Dalla F (2020) Translating evidence from clonal hematopoiesis to cardiovascular disease: A systematic review. J Clin Med 9(8):2480

62. Zhang Q, Zhao K, Shen Q, Han Y, Gu Y, Li X, Zhao D, Liu Y, Wang C, Zhang X, Su X, Liu J, Ge W, Levine RL, Li N, Cao $X(2015)$ Tet2 is required to resolve inflammation by recruiting hdac2 to specifically repress il-6. Nature 525:389-393

63. Swerdlow C, Holmes MV, Kuchenbaecker KB, Engmann JE, Shah T, Sofat R, Guo Y, Chung C, Peasey A, Pfister R, Mooijaart SP, Ireland HA, Leusink M, Langenberg C, Li KW, Palmen J, Howard P, Cooper JA, Drenos F, Hardy J, Nalls MA, Li YR, Lowe G, Stewart M, Bielinski SJ, Peto J, Timpson NJ, Gallacher J, Dunlop M, Houlston R, Tomlinson I, Tzoulaki I, Luan J, Boer JM, Forouhi NG, Onland-Moret NC, van der Schouw YT, Schnabel RB, Hubacek JA, Kubinova R, Baceviciene M, Tamosiunas A, Pajak A, Topor-Madry R, Malyutina S, Baldassarre D, Sennblad B, Tremoli E, de Faire U, Ferrucci L, Bandenelli S, Tanaka T, Meschia JF, Singleton A, Navis G, Mateo Leach I, Bakker SJ, 
Gansevoort RT, Ford I, Epstein SE, Burnett MS, Devaney JM, Jukema JW, Westendorp RG, Jan de Borst G, van der Graaf Y, de Jong PA, Mailand-van der Zee AH, Klungel OH, de Boer A, Doevendans PA, Stephens JW, Eaton CB, Robinson JG, Manson JE, Fowkes FG, Frayling TM, Price JF, Whincup PH, Morris RW, Lawlor DA, Smith GD, Ben-Shlomo Y, Redline S, Lange LA, Kumari M, Wareham NJ, Verschuren WM, Benjamin EJ, Whittaker JC, Hamsten A, Dudbridge F, Delaney JA, Wong A, Kuh D, Hardy R, Castillo BA, Connolly JJ, van der Harst P, Brunner EJ, Marmot MG, Wassel CL, Humphries SE, Talmud PJ, Kivimaki M, Asselbergs FW, Voevoda M, Bobak M, Pikhart H, Wilson JG, Hakonarson H, Reiner AP, Keating BJ, Sattar N, Hingorani AD, Casas JP (2012) The interleukin-6 receptor as a target for prevention of coronary heart disease: A mendelian randomisation analysis. Lancet 379:1214-1224

64. Cai T, Zhang Y, Ho YL, Link N, Sun J, Huang J, Cai TA, Damrauer S, Ahuja Y, Honerlaw J, Huang J, Costa L, Schubert P, Hong C, Gagnon D, Sun YV, Gaziano JM, Wilson P, Cho K, Tsao P, O'Donnell CJ, Liao KP, Program VAMV (2018) Association of interleukin 6 receptor variant with cardiovascular disease effects of interleukin 6 receptor blocking therapy: A phenomewide association study. JAMA Cardiol 3:849-857

65. Cull AH, Snetsinger B, Buckstein R, Wells RA, Rauh MJ (2017) Tet2 restrains inflammatory gene expression in macrophages. Exp Hematol 55(56-70):e13

66. Abplanalp WT, Cremer S, John D, Hoffmann J, Schuhmacher B, Merten M, Rieger MA, Vasa-Nicotera M, Zeiher AM, Dimmeler S (2020) Clonal hematopoiesis-driver dnmt3a mutations alter immune cells in heart failure. Circ Res 128(2):216-228

67. Buscarlet M, Provost S, Zada YF, Bourgoin V, Mollica L, Dube MP, Busque L (2018) Lineage restriction analyses in chip indicate myeloid bias for tet 2 and multipotent stem cell origin for dnmt3a. Blood 132:277-280

68. Arends CM, Galan-Sousa J, Hoyer K, Chan W, Jager M, Yoshida K, Seemann R, Noerenberg D, Waldhueter N, Fleischer-Notter H, Christen F, Schmitt CA, Dorken B, Pelzer U, Sinn M, Zemojtel T, Ogawa S, Mardian S, Schreiber A, Kunitz A, Kruger U, Bullinger L, Mylonas E, Frick M, Damm F (2018) Hematopoietic lineage distribution and evolutionary dynamics of clonal hematopoiesis. Leukemia 32:1908-1919

69. Galli D, Manuguerra R, Monaco R, Manotti L, Goldoni M, Becchi G, Carubbi C, Vignali G, Cucurachi N, Gherli T, Nicolini F, Lorusso R, Vitale M, Corradi D (2017) Understanding the structural features of symptomatic calcific aortic valve stenosis: A broad-spectrum clinico-pathologic study in 236 consecutive surgical cases. Int J Cardiol 228:364-374

70. Manz MG, Boettcher S (2014) Emergency granulopoiesis. Nat Rev Immunol 14:302-314

71. Cai Z, Kotzin JJ, Ramdas B, Chen S, Nelanuthala S, Palam LR, Pandey R, Mali RS, Liu Y, Kelley MR, Sandusky G, Mohseni M, Williams A, Henao-Mejia J, Kapur R (2018) Inhibition of inflammatory signaling in tet 2 mutant preleukemic cells mitigates stress-induced abnormalities and clonal hematopoiesis. Cell Stem Cell 23(833-849):e835

72. Kotzin JJ, Spencer SP, McCright SJ, Kumar DBU, Collet MA, Mowel WK, Elliott EN, Uyar A, Makiya MA, Dunagin MC, Harman CCD, Virtue AT, Zhu S, Bailis W, Stein J, Hughes C, Raj A, Wherry EJ, Goff LA, Klion AD, Rinn JL, Williams A, Flavell RA, Henao-Mejia J (2016) The long non-coding rna morrbid regulates bim and short-lived myeloid cell lifespan. Nature 537:239-243

73. Bick AG, Pirruccello JP, Griffin GK, Gupta N, Gabriel S, Saleheen D, Libby P, Kathiresan S, Natarajan P (2020) Genetic interleukin 6 signaling deficiency attenuates cardiovascular risk in clonal hematopoiesis. Circulation 141:124-131

74. Fulop T, Larbi A, Dupuis G, Le Page A, Frost EH, Cohen AA, Witkowski JM, Franceschi C (1960) Immunosenescence and inflamm-aging as two sides of the same coin: Friends or foes? Front Immunol 2017:8

75. Ferrucci L, Semba RD, Guralnik JM, Ershler WB, Bandinelli S, Patel KV, Sun K, Woodman RC, Andrews NC, Cotter RJ, Ganz T, Nemeth E, Longo DL (2010) Proinflammatory state, hepcidin, and anemia in older persons. Blood 115:3810-3816

76. Jaiswal S, Libby P (2020) Clonal haematopoiesis: Connecting ageing and inflammation in cardiovascular disease. Nat Rev Cardiol 17:137-144

77. Ferrucci L, Fabbri E (2018) Inflammageing: Chronic inflammation in ageing, cardiovascular disease, and frailty. Nat Rev Cardiol 15:505-522

78. Pietras EM (2017) Inflammation: A key regulator of hematopoietic stem cell fate in health and disease. Blood 130:1693-1698

79. Denkinger MD, Leins H, Schirmbeck R, Florian MC, Geiger $\mathrm{H}$ (2015) Hsc aging and senescent immune remodeling. Trends Immunol 36:815-824

80. He H, Xu P, Zhang X, Liao M, Dong Q, Cong T, Tang B, Yang X, Ye M, Chang Y, Liu W, Wang X, Ju Z, Wang J (2020) Aginginduced il27ra signaling impairs hematopoietic stem cells. Blood 136:183-198

81. Kovtonyuk LV, Fritsch K, Feng X, Manz MG, Takizawa H (2016) Inflamm-aging of hematopoiesis, hematopoietic stem cells, and the bone marrow microenvironment. Front Immunol 7:502

82. Matatall KA, Shen CC, Challen GA, King KY (2014) Type ii interferon promotes differentiation of myeloid-biased hematopoietic stem cells. Stem Cells 32:3023-3030

83. Matatall KA, Jeong M, Chen S, Sun D, Chen F, Mo Q, Kimmel M, King KY (2016) Chronic infection depletes hematopoietic stem cells through stress-induced terminal differentiation. Cell Rep 17:2584-2595

84. Pietras EM, Mirantes-Barbeito C, Fong S, Loeffler D, Kovtonyuk LV, Zhang S, Lakshminarasimhan R, Chin CP, Techner JM, Will B, Nerlov C, Steidl U, Manz MG, Schroeder T, Passegue E (2016) Chronic interleukin-1 exposure drives haematopoietic stem cells towards precocious myeloid differentiation at the expense of self-renewal. Nat Cell Biol 18:607-618

85. Beaulieu LM, Lin E, Mick E, Koupenova M, Weinberg EO, Kramer CD, Genco CA, Tanriverdi K, Larson MG, Benjamin EJ, Freedman JE (2014) Interleukin 1 receptor 1 and interleukin 1beta regulate megakaryocyte maturation, platelet activation, and transcript profile during inflammation in mice and humans. Arterioscler Thromb Vasc Biol 34:552-564

86. Nishimura S, Nagasaki M, Kunishima S, Sawaguchi A, Sakata A, Sakaguchi H, Ohmori T, Manabe I, Italiano JE Jr, Ryu T, Takayama N, Komuro I, Kadowaki T, Eto K, Nagai R (2015) Il1alpha induces thrombopoiesis through megakaryocyte rupture in response to acute platelet needs. J Cell Biol 209:453-466

87. Grover A, Sanjuan-Pla A, Thongjuea S, Carrelha J, Giustacchini A, Gambardella A, Macaulay I, Mancini E, Luis TC, Mead A, Jacobsen SE, Nerlov C (2016) Single-cell rna sequencing reveals molecular and functional platelet bias of aged haematopoietic stem cells. Nat Commun 7:11075

88. Frisch BJ, Hoffman CM, Latchney SE, LaMere MW, Myers J, Ashton J, Li AJ, Saunders J 2nd, Palis J, Perkins AS, McCabe A, Smith JN, McGrath KE, Rivera-Escalera F, McDavid A, Liesveld JL, Korshunov VA, Elliott MR, MacNamara KC, Becker MW, Calvi LM (2019) Aged marrow macrophages expand platelet-biased hematopoietic stem cells via interleukin1b. JCI Insight. https://doi.org/10.1172/jci.insight.124213 
89. Haas S, Hansson J, Klimmeck D, Loeffler D, Velten L, Uckelmann H, Wurzer S, Prendergast AM, Schnell A, Hexel K, Santarella-Mellwig R, Blaszkiewicz S, Kuck A, Geiger H, Milsom MD, Steinmetz LM, Schroeder T, Trumpp A, Krijgsveld J, Essers MA (2015) Inflammation-induced emergency megakaryopoiesis driven by hematopoietic stem cell-like megakaryocyte progenitors. Cell Stem Cell 17:422-434

90. Takizawa H, Fritsch K, Kovtonyuk LV, Saito Y, Yakkala C, Jacobs K, Ahuja AK, Lopes M, Hausmann A, Hardt WD, Gomariz A, Nombela-Arrieta C, Manz MG (2017) Pathogeninduced tlr4-trif innate immune signaling in hematopoietic stem cells promotes proliferation but reduces competitive fitness. Cell Stem Cell 21(225-240):e225

91. Guillamot M, Cimmino L, Aifantis I (2016) The impact of DNA methylation in hematopoietic malignancies. Trends Cancer 2:70-83

92. Cimmino L, Dolgalev I, Wang Y, Yoshimi A, Martin GH, Wang J, Ng V, Xia B, Witkowski MT, Mitchell-Flack M, Grillo I, Bakogianni S, Ndiaye-Lobry D, Martin MT, Guillamot M, Banh RS, Xu M, Figueroa ME, Dickins RA, Abdel-Wahab O, Park CY, Tsirigos A, Neel BG, Aifantis I (2017) Restoration of tet 2 function blocks aberrant self-renewal and leukemia progression. Cell 170(1079-1095):e1020

93. Young JI, Zuchner S, Wang G (2015) Regulation of the epigenome by vitamin c. Annu Rev Nutr 35:545-564

94. Zhao H, Zhu H, Huang J, Zhu Y, Hong M, Zhu H, Zhang J, Li S, Yang L, Lian Y, Wang S, Mao J, Chen Y, Li J, Qian S (2018) The synergy of vitamin c with decitabine activates tet2 in leukemic cells and significantly improves overall survival in elderly patients with acute myeloid leukemia. Leuk Res 66:1-7

95. Das AB, Kakadia PM, Wojcik D, Pemberton L, Browett PJ, Bohlander SK, Vissers MCM (2019) Clinical remission following ascorbate treatment in a case of acute myeloid leukemia with mutations in tet2 and wt1. Blood Cancer J 9:82

96. Yang X, Jia J, Yu Z, Duanmu Z, He H, Chen S, Qu C (2020) Inhibition of jak2/stat3/socs3 signaling attenuates atherosclerosis in rabbit. BMC Cardiovasc Disord 20:133

97. Tang Y, Liu W, Wang W, Fidler T, Woods B, Levine RL, Tall AR, Wang N (2020) Inhibition of jak2 suppresses myelopoiesis and atherosclerosis in apoe(-/-) mice. Cardiovasc Drugs Ther 34:145-152

98. Jiang H, Yu Z, Ding N, Yang M, Zhang L, Fan X, Zhou Y, Zou Q, Hou J, Zheng J, Zhang L, Xu Y, Liu J (2020) The role of agk in thrombocytopoiesis and possible therapeutic strategies. Blood 136:119-129

99. Gallagher EJ, LeRoith D (2015) Obesity and diabetes: The increased risk of cancer and cancer-related mortality. Physiol Rev 95:727-748

100. Wu D, Hu D, Chen H, Shi G, Fetahu IS, Wu F, Rabidou K, Fang R, Tan L, Xu S, Liu H, Argueta C, Zhang L, Mao F, Yan G, Chen J, Dong Z, Lv R, Xu Y, Wang M, Ye Y, Zhang S, Duquette D, Geng S, Yin C, Lian CG, Murphy GF, Adler GK, Garg R, Lynch L, Yang P, Li Y, Lan F, Fan J, Shi Y, Shi YG (2018) Glucoseregulated phosphorylation of tet 2 by ampk reveals a pathway linking diabetes to cancer. Nature 559:637-641

101. Sniderman AD, Furberg CD (2008) Age as a modifiable risk factor for cardiovascular disease. Lancet 371:1547-1549

102. Mas-Peiro S, Hoffmann J, Fichtlscherer S, Dorsheimer L, Rieger MA, Dimmeler S, Vasa-Nicotera M, Zeiher AM (2020) Clonal haematopoiesis in patients with degenerative aortic valve stenosis undergoing transcatheter aortic valve implantation. Eur Heart J 41:933-939

Publisher's Note Springer Nature remains neutral with regard to jurisdictional claims in published maps and institutional affiliations. 